Supporting information

\title{
In vivo half-life extension of BMP1/TLL metalloproteinase inhibitors using small-molecule human serum albumin binders
}

Julien C. Vantourout, ${ }^{\mathrm{a}, \mathrm{b}}$ Andrew M. Mason, \&a Josephine Yuen, \&c Graham L. Simpson, ${ }^{\mathrm{a}}$ Ghotas

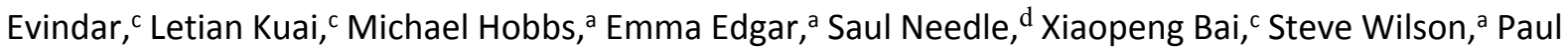
Scott-Stevens, ${ }^{\text {a }}$ William Traylen, ${ }^{a}$ Kim Lambert, ${ }^{a}$ Neil Young, ${ }^{a}$ Shenaz Bunally, ${ }^{a}$ Scott G. Summerfield, ${ }^{a}$ Richard Snell, ${ }^{a}$ Rakesh Lad, ${ }^{a}$ Eric Shi, ${ }^{c}$ Steven Skinner, ${ }^{c}$ Lisa Shewchuk, ${ }^{d}$ Allan J.B. Watson, ${ }^{\text {e Chun-wa }}$ Chung, ${ }^{a}$ Sandeep Pal, a Dennis A. Holt, ${ }^{\mathrm{d}}$ Lara S. Kallander, ${ }^{\mathrm{d}}$ Joanne Prendergast, ${ }^{\mathrm{d}}$ Katrina Rivera, ${ }^{\mathrm{d}}$ David G. Washburn, ${ }^{\mathrm{d}}$ Mark R. Harpel, ${ }^{* \mathrm{~d}}$ Christopher Arico-Muendel, ${ }^{* c}$ Albert Isidro-Llobet*a

\& These authors contributed equally to the study

a GlaxoSmithKline UK, Gunnels Wood Road, Stevenage, Hertfordshire, SG1 2NY, UK.

${ }^{b}$ Department of Pure and Applied Chemistry, University of Strathclyde, 295 Cathedral Street, Glasgow, G11XL, UK.

' GlaxoSmithKline US, 200 Cambridge Park Drive, Cambridge, MA 02140, US.

d GlaxoSmithKline US, 1250 South Collegeville Road, Collegeville, PA 19426, US.

e University of St Andrews, North Haugh, St Andrews, KY16 9ST, UK

Corresponding Authors

*E-mail: albert.x.isidro-llobet@gsk.com

*E-mail: christopher.c.arico-muendel@gsk.com

*E-mail: mark.r.harpel@gsk.com 
This file includes:

Procedures for the synthesis of compounds used in the publication 


\section{NMR Spectroscopy}

${ }^{1} \mathrm{H}$ NMR and ${ }^{13} \mathrm{C}$ NMR spectra were acquired and processed on a Bruker AVIII $400 \mathrm{MHz}$ instrument with a $5 \mathrm{~mm}$ BBO probe. Chemical shifts $(\delta)$ are reported in parts per million (ppm) and referenced to the residual solvent peak. Coupling constants $(J)$ are measured in hertz $(\mathrm{Hz})$. Advanced experiments were acquired and processed on a Bruker AVII+ $600 \mathrm{MHz}$ instrument with a $5 \mathrm{~mm} \mathrm{CPTCl}$ cryo-probe. These were obtained by Sean Lynn of the Analytical Chemistry Department, GlaxoSmithKline, Stevenage.

\section{Mass Spectrometry}

\section{High Resolution Mass Spectroscopy (HRMS)}

Positive ion mass spectra were acquired using a Waters XEVO G2-XS Qtof mass spectrometer, equipped with an ESI interface, over a mass range of $100-1200 \mathrm{Da}$, with a scan time of 0.5 sec. The elemental composition was calculated using Masslynx software and processed for either the $[\mathrm{M}+\mathrm{H}]+,[\mathrm{M}+2 \mathrm{H}] 2+/ 2,[\mathrm{M}+3 \mathrm{H}] 3+/ 3$ or $[\mathrm{M}+\mathrm{Na}]+$ ion and the mass error quoted as ppm.

\section{Low resolution mass spectra (LC-MS) were recorded using one of four methods:}

1) System A: (Formic)

An Acquity UPLC CSH C18 column ( $50 \mathrm{~mm} \times 2.1 \mathrm{~mm}$ i.d. $1.7 \mu \mathrm{m}$ packing diameter) eluting with $0.1 \%$ formic acid in water (solvent $A$ ), and $0.1 \%$ formic acid in acetonitrile (solvent $B$ ), using the following elution gradient $0.0-1.5 \mathrm{~min} 3-100 \% \mathrm{~B}, 1.5-1.9 \min 100 \% \mathrm{~B}, 1.9-2.0 \min 100-3 \%$ $\mathrm{B}$, at a flow rate of $1 \mathrm{mLmin}-1$ at $40^{\circ} \mathrm{C}$.

2) System B: (HpH) An Acquity UPLC CSH C18 column ( $50 \mathrm{~mm} \times 2.1 \mathrm{~mm}$ i.d. $1.7 \mu \mathrm{m}$ packing diameter) eluting with 10 $\mathrm{mM} \mathrm{NH}_{4} \mathrm{HCO}_{3}$ in water adjusted to $\mathrm{pH} 10$ with aqueous ammonia (solvent $\mathrm{A}$ ), and acetonitrile (solvent B), using the following elution gradient: $0.0-1.5 \min 3-95 \%$ B, $1.5-1.9 \min 95 \%$ B, $1.9-2.0 \min 95$ $-3 \% \mathrm{~B}$, at a flow-rate of $1 \mathrm{mLmin}-1$ at $40^{\circ} \mathrm{C}$. The UV detection was an averaged signal from wavelength of $210 \mathrm{~nm}$ to $350 \mathrm{~nm}$, and mass spectra were recorded on a mass spectrometer using alternate-scan electrospray positive and negative mode ionisation (ES+ve and ES-ve)

3) System D: (TFA)

The UPLC analysis was conducted on an Acquity UPLC BEH C18 column (100mm x $2.1 \mathrm{~mm}$ packing diameter) eluting with $0.1 \%$ trifluoroacetic in water (solvent $A$ ), and $0.1 \%$ trifluoroacetic in acetonitrile (solvent B), using the following elution gradient $0.0-8.5 \mathrm{~min} 3-100 \% \mathrm{~B}, 8.5 \mathrm{~min}-9.0 \mathrm{~min} 100 \% \mathrm{~B}$, $9.0 \min -10 \min 100 \%-3 \% \mathrm{~B}$, at $50^{\circ} \mathrm{C}$.

4) System D: (Formic)

The UPLC analysis was conducted on an Acquity UPLC CSH C18 column $(100 \mathrm{~mm} \times 2.1 \mathrm{~mm}$ i.d. $1.7 \mu \mathrm{m}$ packing diameter) eluting with $0.1 \%$ formic acid in water (solvent $A$ ), and $0.1 \%$ formic acid in acetonitrile (solvent $B$ ), using the following elution gradient $0.0-8.5 \mathrm{~min} 3-100 \% \mathrm{~B}, 8.5 \mathrm{~min}-9.0$ $\min 100 \% \mathrm{~B}, 9.0 \mathrm{~min}-10 \mathrm{~min} 100 \%-3 \% \mathrm{~B}$, at $50^{\circ} \mathrm{C}$.

\section{Chromatography}

\section{Normal phase}

Column chromatography was performed on a Isolera purification system. The Isolera is an automated multi-user flash chromatography system, available from Biotage, which utilizes disposable, normal phase pre-packed silica, and C18 reverse phase cartridges (1 g to $340 \mathrm{~g}$ ). 


\section{Reverse phase}

Method A - Crude reaction mixtures were dissolved in the minimum amount of DMSO and loaded onto a pre-packed Biotage ${ }^{\circledR} \mathrm{C} 18$ modified silica cartridge. Flash column chromatography was carried out using the Biotage Isolera apparatus.

Method B - Crude reaction mixtures were dissolved in the minimum amount of DMSO and purified on XBridge Shield reverse phase C18 column ( $150 \mathrm{~mm} \times 30 \mathrm{~mm}, 5 \mu \mathrm{m}$ packing diameter, 40 $\mathrm{mL} / \mathrm{min}$ flow rate). Gradient elution at ambient temperature with the mobile phases as (A) $10 \mathrm{mM}$ aqueous ammonium bicarbonate solution, adjusted to $\mathrm{pH} 10$ with $0.88 \mathrm{M}$ aqueous ammonia and (B) methanol. Purification was carried out using Waters ZQ MS using positive electrospray and a summed UV wavelength of $210-350 \mathrm{~nm}$.

Mass directed auto purification (MDAP). Mass-directed automatic purification was carried out using an $\mathrm{H}_{2} \mathrm{Os} \mathrm{ZQ}$ MS using alternate-scan positive and negative electrospray and a summed UV wavelength of 210-350 nm. Crude reaction mixtures were dissolved in 1:1 DMSO:MeOH (1 mL). Two liquid phase methods were used:

Method A - Formic - XSelect CSH Prep C18 column $(150 \mathrm{~mm} \times 30 \mathrm{~mm}, 5 \mu \mathrm{m}$ packing diameter, $40 \mathrm{~mL} / \mathrm{min}$ flow rate). Gradient elution at ambient temperature with the mobile phases as (A) $\mathrm{H} 2 \mathrm{O}$ containing $0.1 \%$ volume/volume $(\mathrm{v} / \mathrm{v})$ formic acid and $(\mathrm{B})$ acetonitrile containing $0.1 \%(\mathrm{v} / \mathrm{v})$ formic acid.

Method B - High pH - XSelect CSH Prep C18 column (150 mm $\times 30 \mathrm{~mm}, 5 \mu \mathrm{m}$ packing diameter, $40 \mathrm{~mL} / \mathrm{min}$ flow rate). Gradient elution at ambient temperature with the mobile phases as (A) 10 $\mathrm{mM}$ aqueous ammonium bicarbonate solution, adjusted to $\mathrm{pH} 10$ with $0.88 \mathrm{M}$ aqueous ammonia and (B) acetonitrile.

All reagents were used as purchased from commercial suppliers. Solvents were purchased from Sigma Aldrich, anhydrous, sure-seal quality, and used with no further purification. Reactions were carried out in a fume hood, under a nitrogen atmosphere, unless otherwise stated.Synthesis of conjugates 


\section{Synthesis protocols}

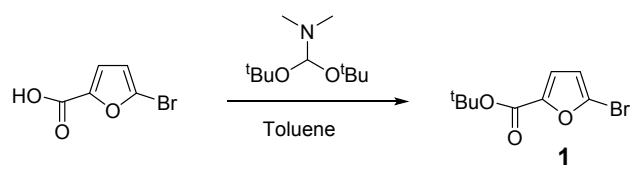

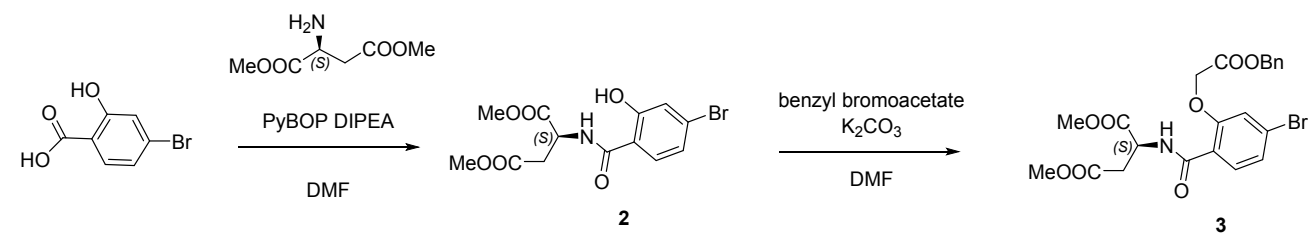

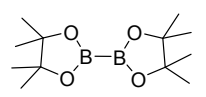

$\mathrm{Pd}(\mathrm{dppf}) \mathrm{Cl}_{2} \mathrm{DCM}$

$\underset{\text { 1,4-dioxane }}{\mathrm{KOAC}}$

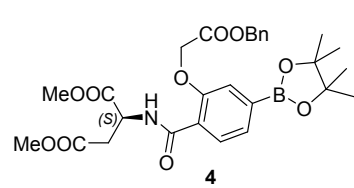

4

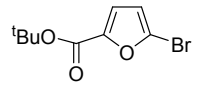

XPhos Pd G2, XPhos

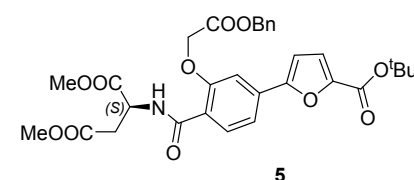

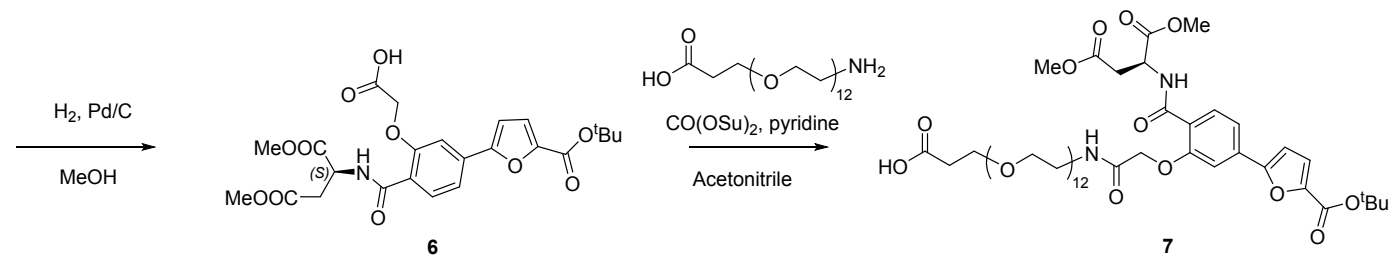<smiles>COC(=O)CC(NC(=O)c1ccc(-c2ccc(C(=O)O)o2)cc1OCC(=O)NCCOC(C)(C)CCC(=O)NCCOCCOCCNC(=O)c1cccc(NC(=O)OC2CCN(C(=O)c3ccc(-c4nc5ccccc5[nH]4)cc3)CC2)c1)C(=O)OC</smiles>
10 $\prod_{\mathrm{O}}^{\mathrm{OH}}$

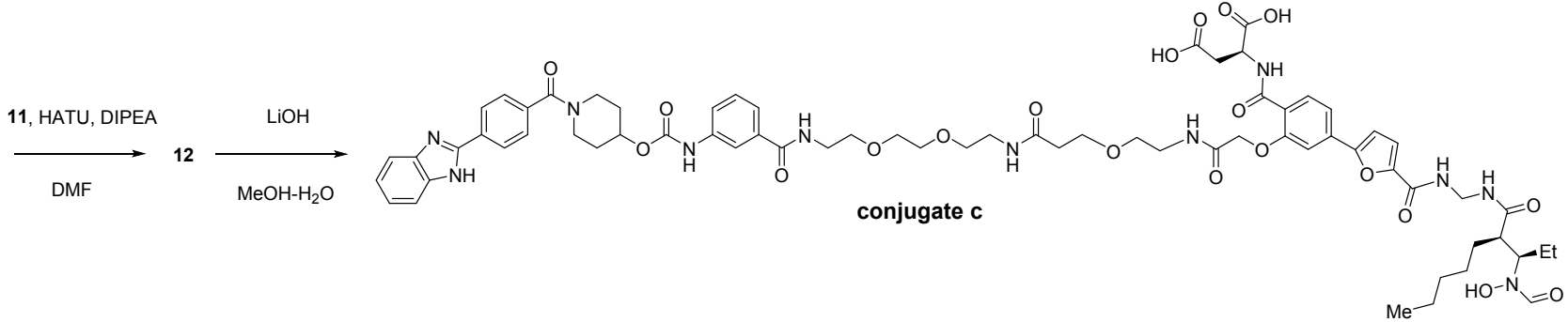<smiles>NCCOCCOCCNC(=O)c1cccc(NC(=O)OC2CCN(C(=O)c3ccc(-c4nc5ccccc5[nH]4)cc3)CC2)c1</smiles><smiles>CCCCCC(C(=O)NCN)C(CC)N(O)C=O</smiles>

11

Scheme S1. Synthesis of conjugate c 


\section{tert-Butyl 5-bromofuran-2-carboxylate (1)}<smiles>CCCCOC(=O)c1ccc(Br)o1</smiles>

$\mathrm{N}, \mathrm{N}$-dimethylformamide di-tert-butyl acetal $(6.28 \mathrm{~mL}, 26.2 \mathrm{mmol})$ was added to a supension of 5bromofuran-2-carboxylic acid $(2 \mathrm{~g}, 10.47 \mathrm{mmol})$ in toluene $(10 \mathrm{~mL})$ under nitrogen and the resulting solution heated to $80^{\circ} \mathrm{C}$, under nitrogen, for 2 hours. An additional amount of $\mathrm{N}, \mathrm{N}$-dimethylformamide di-tert-butyl acetal $(6.28 \mathrm{~mL}, 26.2 \mathrm{mmol})$ was addded and the mixture heated to $80^{\circ} \mathrm{C}$ for a further 4 hours. The mixture was then concentrated under reduced pressure and the residue partitioned between ethyl acetate and saturated aqueous sodium bicarbonate. The organic phase was separated and washed with brine, dried over magnesium sulfate, filtered and concentrated. The crude product was purified by flash chromatography [0 -100\% diethylether/cyclohexane] to provide 1 (1.2 g, $46 \%$ yield). ${ }^{1} \mathrm{H}$ NMR (400 MHz, $\mathrm{CDCl}_{3}$ ): $\delta 7.03(\mathrm{~d}, 1 \mathrm{H}), 6.43(\mathrm{~d}, J=3.5 \mathrm{~Hz}, 1 \mathrm{H}), 1.59$ (d, J=3.5 Hz, 1H). MS: $[\mathrm{M}+\mathrm{H}]^{+}$191, 193 (loss of $\mathrm{tBu}$ )

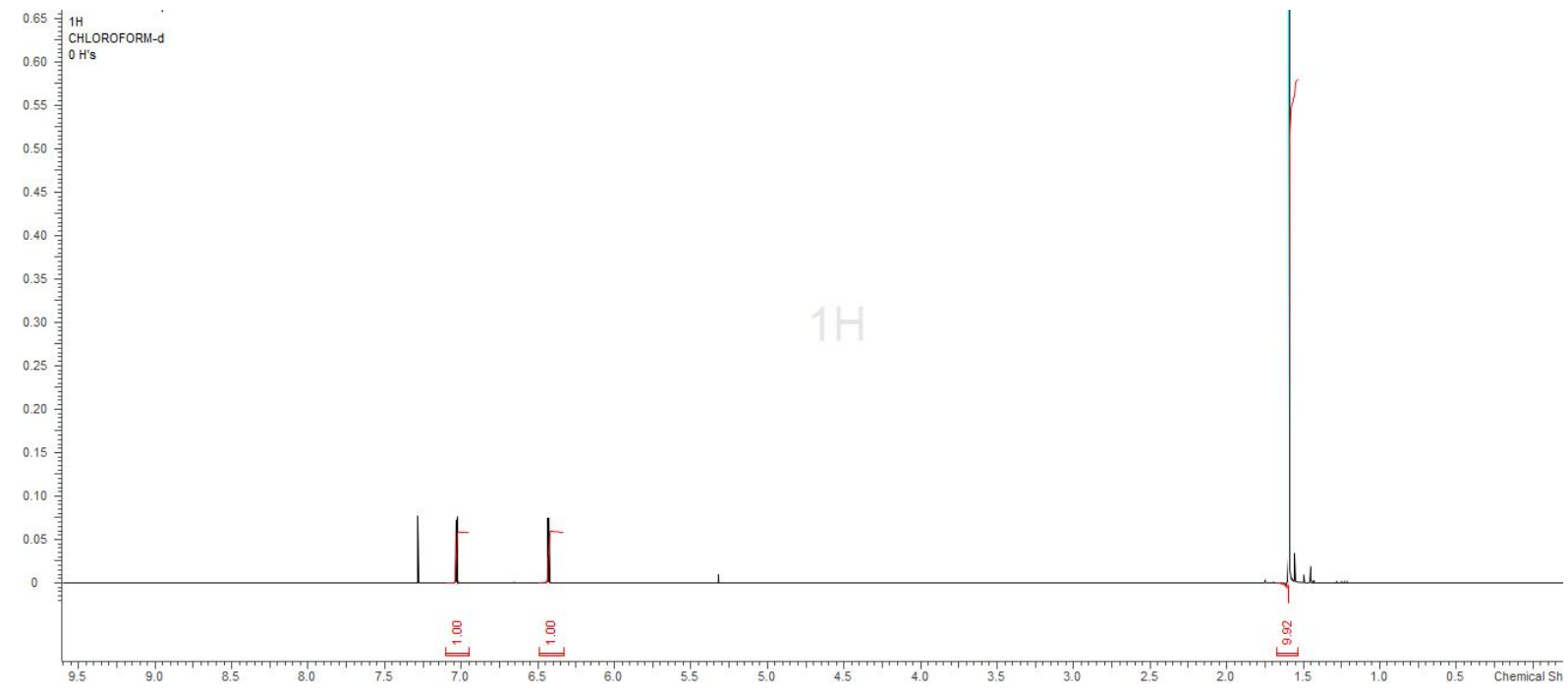

SAMPLE: 2:26 3:Combine (120:125-(110:111+135:136))
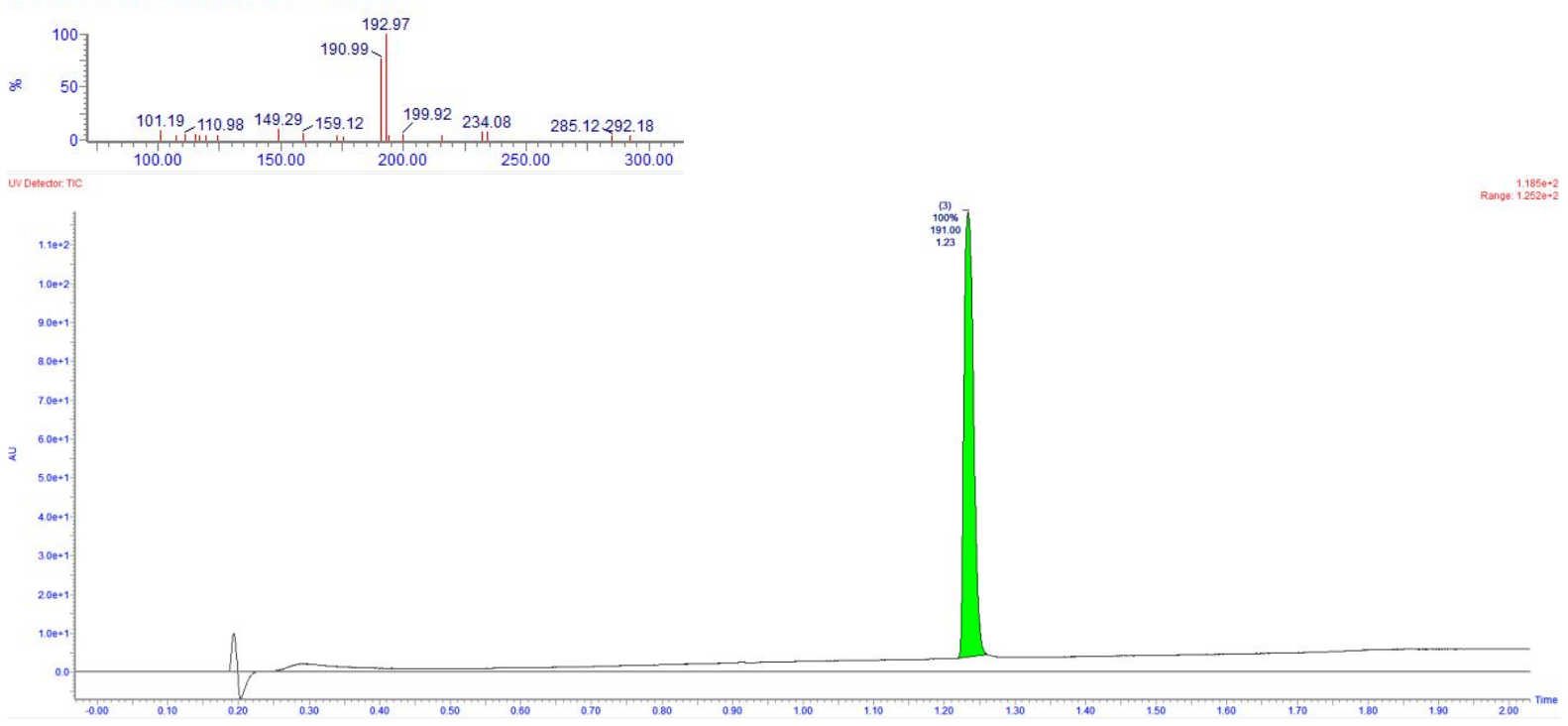
Dimethyl (4-bromo-2-hydroxybenzoyl)-L-aspartate (2)<smiles>COC(=O)C[C@H](CC(C)=O)NC(=O)c1ccc(Br)cc1O</smiles>

A mixture of 4-bromo-2-hydroxybenzoic acid $(1.0 \mathrm{~g}, 4.61 \mathrm{mmol})$, PyBOP $(2.398 \mathrm{~g}, 4.61 \mathrm{mmol})$ and DIPEA ( $2.414 \mathrm{~mL}, 13.82 \mathrm{mmol}$ ) in N,N-Dimethylformamide $(5 \mathrm{~mL}$ ) was stirred at room temperature for $15 \mathrm{~min}$. (S)-dimethyl 2-aminosuccinate $(0.911 \mathrm{~g}, 4.61 \mathrm{mmol})$ was added and the solution stirred at room temperature for $14 \mathrm{~h}$. The mixture was partitioned between DCM and saturated aqueous lithium chloride. The organic phase was separated and washed sequentially with saturated aqueous sodium bicarbonate, $2 \mathrm{~N}$ hydrochloric acid, brine, and dried over magnesium sulfate, filtered and concentrated under reduced pressure. The crude product was purified by flash chromatography $[0-55 \%$ EtOAc /cyclohexane] to provide 2 (1.2 g, $70 \%$ yield). ${ }^{1} \mathrm{H}$ NMR $\left(400 \mathrm{MHz}, \mathrm{CDCl}_{3}+\mathrm{D}_{2} \mathrm{O}\right): 7.28-7.38(\mathrm{~d}, J=8.5 \mathrm{~Hz}$, $1 \mathrm{H}), 7.18(\mathrm{~d}, J=1.9 \mathrm{~Hz}, 1 \mathrm{H}$ ), 7.02 (dd, J=8.5, $1.9 \mathrm{~Hz}, 1 \mathrm{H}$ ), 5.02 (t, J=4.4 Hz, $1 \mathrm{H}$ ), $3.81(\mathrm{~S}, 3 \mathrm{H}), 3.72$ (S, $3 \mathrm{H}), 2.93-3.23(\mathrm{~m}, 2 \mathrm{H}) \mathrm{MS}:[\mathrm{M}+\mathrm{H}]^{+} 360,362$

${ }^{1} \mathrm{H} \mathrm{NMR}\left(400 \mathrm{MHz}, \mathrm{CDCl}_{3}\right)$ contains residual EtOAc

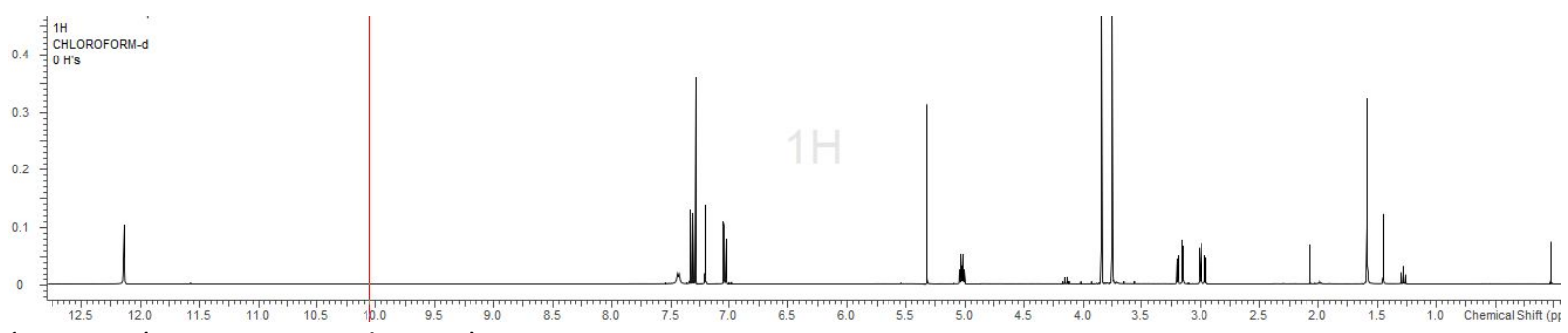

${ }^{1} \mathrm{H}$ NMR $\left(400 \mathrm{MHz}, \mathrm{CDCl}_{3}+\mathrm{D}_{2} \mathrm{O}\right)$
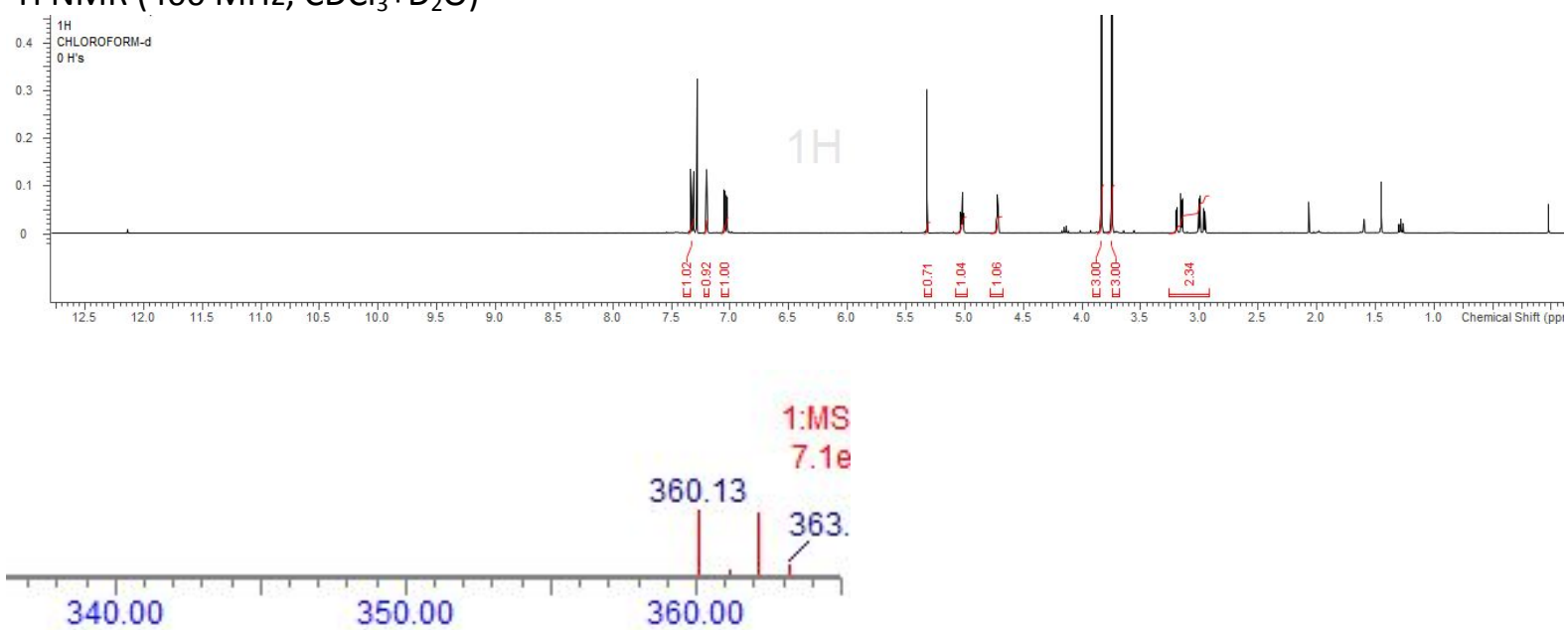


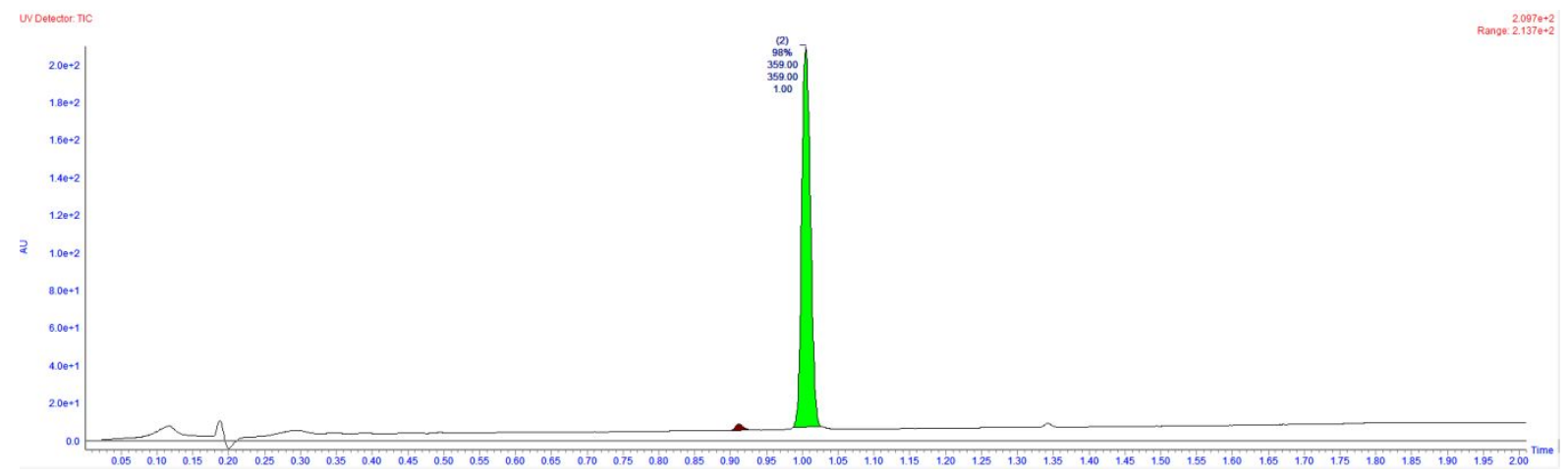

Dimethyl (2-(2-(benzyloxy)-2-oxoethoxy)-4-bromobenzoyl)-L-aspartate (3)<smiles>COC(=O)C[C@@H](NC(=O)c1ccc(Br)cc1OCC(=O)OCc1ccccc1)C(=O)OC</smiles>

A mixture of anhydrous potassium carbonate (potassium carbonate $(0.725 \mathrm{~g}, 5.25 \mathrm{mmol}), 2(0.945 \mathrm{~g}$, $2.62 \mathrm{mmol}$ ) and benzyl bromoacetate $(0.501 \mathrm{ml}, 3.15 \mathrm{mmol}$ ) in anhydrous $\mathrm{N}, \mathrm{N}$-Dimethylformamide (3 $\mathrm{mL}$ ) was stirred for $24 \mathrm{~h}$ at room temperature. The mixture was partitioned between EtOAc and water. The organic phase was washed with saturated aqueous lithium chloride solution, brine, dried over magnesium sulfate, filtered and concentrated under reduced pressure. The product was purified by flash chromatography, silica gel [0 - 100\% ethyl acetate / cyclohexane] to provide 3 ( $1.2 \mathrm{~g}, 89 \%$ yield). ${ }^{1} \mathrm{H}$ NMR $\left(400 \mathrm{MHz}, \mathrm{CDCl}_{3}\right): 8.87(\mathrm{br} \mathrm{d}, J=8.1 \mathrm{~Hz}, 1 \mathrm{H}), 8.07(\mathrm{~d}, J=8.6 \mathrm{~Hz}, 1 \mathrm{H}), 7.33-7.41(\mathrm{~m}, 5$ H), 7.22-7.29 (dd, $J=8.6,1.5 \mathrm{~Hz}, 1 \mathrm{H}) 7.00$ (d, $J=1.5 \mathrm{~Hz}, 1 \mathrm{H}), 5.28(\mathrm{~s}, 2 \mathrm{H}), 5.08(\mathrm{~m}, 1 \mathrm{H}), 4.75$ - $4.86(\mathrm{~m}, 2 \mathrm{H}), 3.76(\mathrm{~s}, 3 \mathrm{H}), 3.67(\mathrm{~s}, 3 \mathrm{H}), 2.95-3.10(\mathrm{~m}, 2 \mathrm{H}) \mathrm{MS}:[\mathrm{M}+\mathrm{H}]^{+} 508,510$

${ }^{1} \mathrm{H}$ NMR $\left(400 \mathrm{MHz}, \mathrm{CDCl}_{3}\right)$

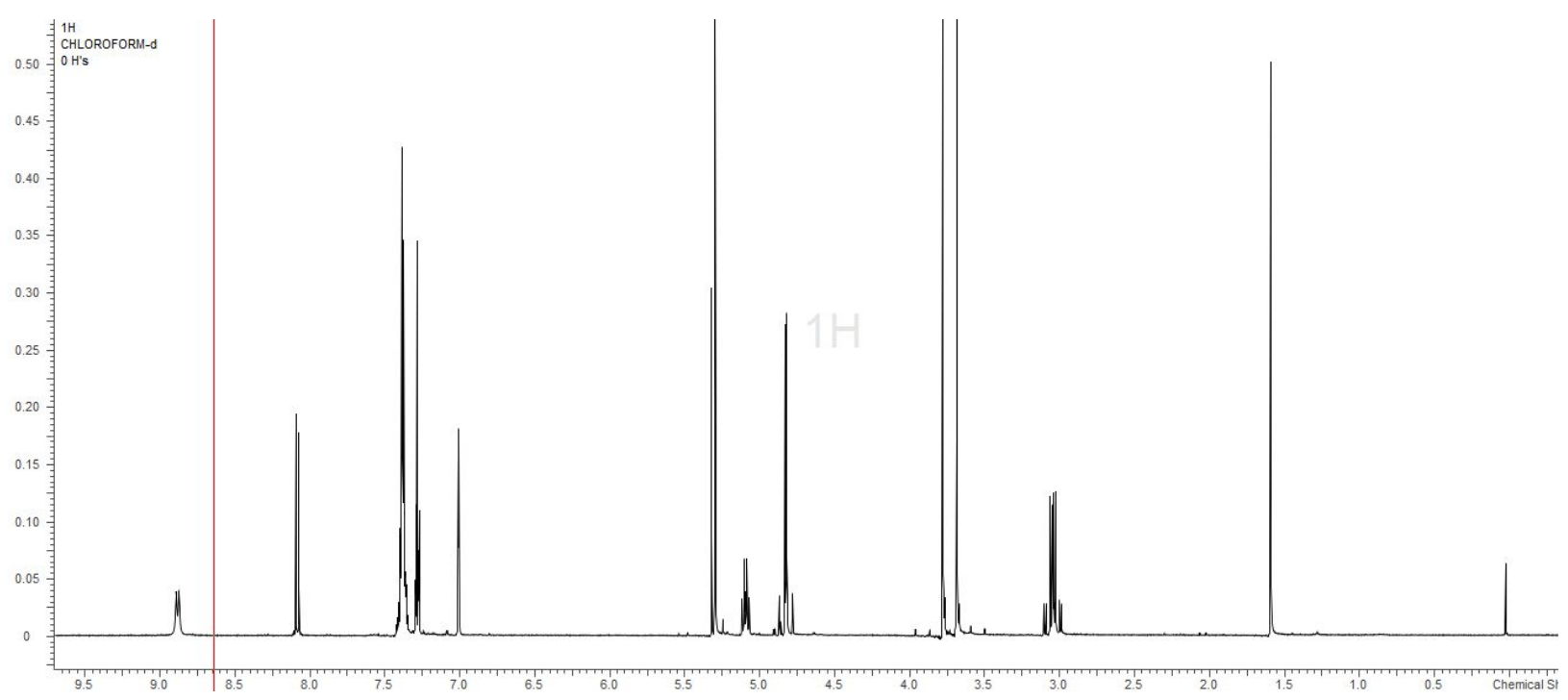



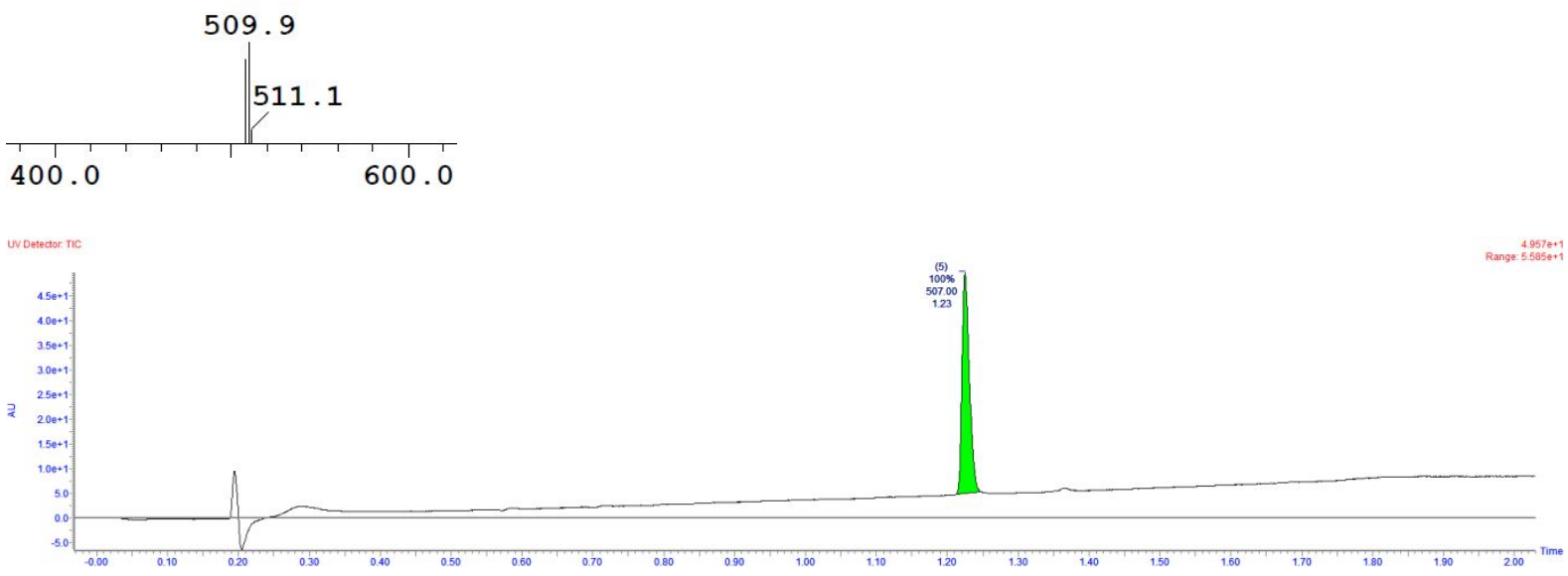

Dimethyl (2-(2-(benzyloxy)-2-oxoethoxy)-4-(5-(tert-butoxycarbonyl)furan-2-yl)benzoyl)-L-aspartate

(5)<smiles>CCCCOC(=O)c1ccc(-c2ccc(C(=O)N[C@@H](CC(=O)OC)C(C)C)c(OCC(=O)OCc3ccccc3)c2)o1</smiles>

3 (1.015 g, $1.997 \mathrm{mmol})$ was dissolved in 1,4-dioxane $(6 \mathrm{~mL})$ and treated with bis(pinacolato)diboron $(0.761 \mathrm{~g}, 3.00 \mathrm{mmol})$ and $\mathrm{Pd}(\mathrm{dppf}) \mathrm{Cl} 2 \cdot \mathrm{CH} 2 \mathrm{Cl} 2(0.146 \mathrm{~g}, 0.200 \mathrm{mmol})$ followed by potassium acetate $(0.980 \mathrm{~g}, 9.98 \mathrm{mmol})$ at room temperature. The reaction was heated at $40{ }^{\circ} \mathrm{C}$ for $5 \mathrm{~h}$. Extra with bis(pinacolato)diboron ( $1 \mathrm{mmol}$ ) was added and the reaction mixture was stirred overnight at room temperature. The reaction temperature was raised to $60^{\circ} \mathrm{C}$ and heated for an extra $3 \mathrm{~h}$. The mixture was partitioned between EtOAc and brine. The organic phase was filtered through Celite and evaporated. The product was purified purified by flash chromatography on silica gel $[100 \mathrm{~g}, 0-100 \%$ Ethyl acetate/ cyclohexane] to provide impure $4(1.33 \mathrm{~g}, 2.395 \mathrm{mmol}, 120 \%$ yield)- still contains pinacol related material and unreacted $\mathrm{sm} \sim 5 \%$. A mixture of 1 (400 mg, $1.619 \mathrm{mmol}), 4(1.08 \mathrm{~g}, 1.94$ mmol, 1eq based on purity), XPhos Pd G2 (96 mg, $0.121 \mathrm{mmol}$ ), XPhos (116 mg, $0.243 \mathrm{mmol}$ ) and $\mathrm{K}_{3} \mathrm{PO}_{4}(1.03 \mathrm{~g}, 4.86 \mathrm{mmol})$ in degassed dry THF $(10 \mathrm{~mL})$ and water $(2 \mathrm{~mL})$ was stirred at room temperature for $5 \mathrm{~h}$. The reaction mixture was partitioned between EtOAc and brine, and the organic phase dried over magnesium sulfate, filtered through celite and concentrated under reduced pressure. The product was purified by flash chromatography, silica gel [0 to $100 \%$ ethyl acetate / cyclohexane) to provide 5 (650 mg, 67\% yield, over two steps). ${ }^{1} \mathrm{H} \mathrm{NMR} \mathrm{(400} \mathrm{MHz,} \mathrm{CDCl}_{3}$ ): 9.02 (d, $\mathrm{J}=7.5 \mathrm{~Hz}, 1 \mathrm{H}$ ), 8.26 (d, $J=8.1 \mathrm{~Hz}, 1 \mathrm{H}$ ), 7.47 (dd, $J=8.1,1.5 \mathrm{~Hz}, 1 \mathrm{H}), 7.35-7.40(\mathrm{~m}, 5 \mathrm{H}), 7.27$ $(\mathrm{d}, 1.5 \mathrm{~Hz}, 1 \mathrm{H}), 7.14(\mathrm{~d}, J=3.5 \mathrm{~Hz}, 1 \mathrm{H}), 6.77(\mathrm{~d}, J=3.5 \mathrm{~Hz}, 1 \mathrm{H}), 5.31(\mathrm{~s}, 2 \mathrm{H}), 5.09-5.15(\mathrm{~m}, 1$ H), 4.87-4.97 (m, $2 \mathrm{H}), 3.78(\mathrm{~s}, 3 \mathrm{H}), 3.70(\mathrm{~s}, 3 \mathrm{H}), 3.06(\mathrm{~m}, 2 \mathrm{H}), 1.63(\mathrm{~s}, 9 \mathrm{H}) \mathrm{MS}:[\mathrm{M}+\mathrm{H}]^{+} 596$ 

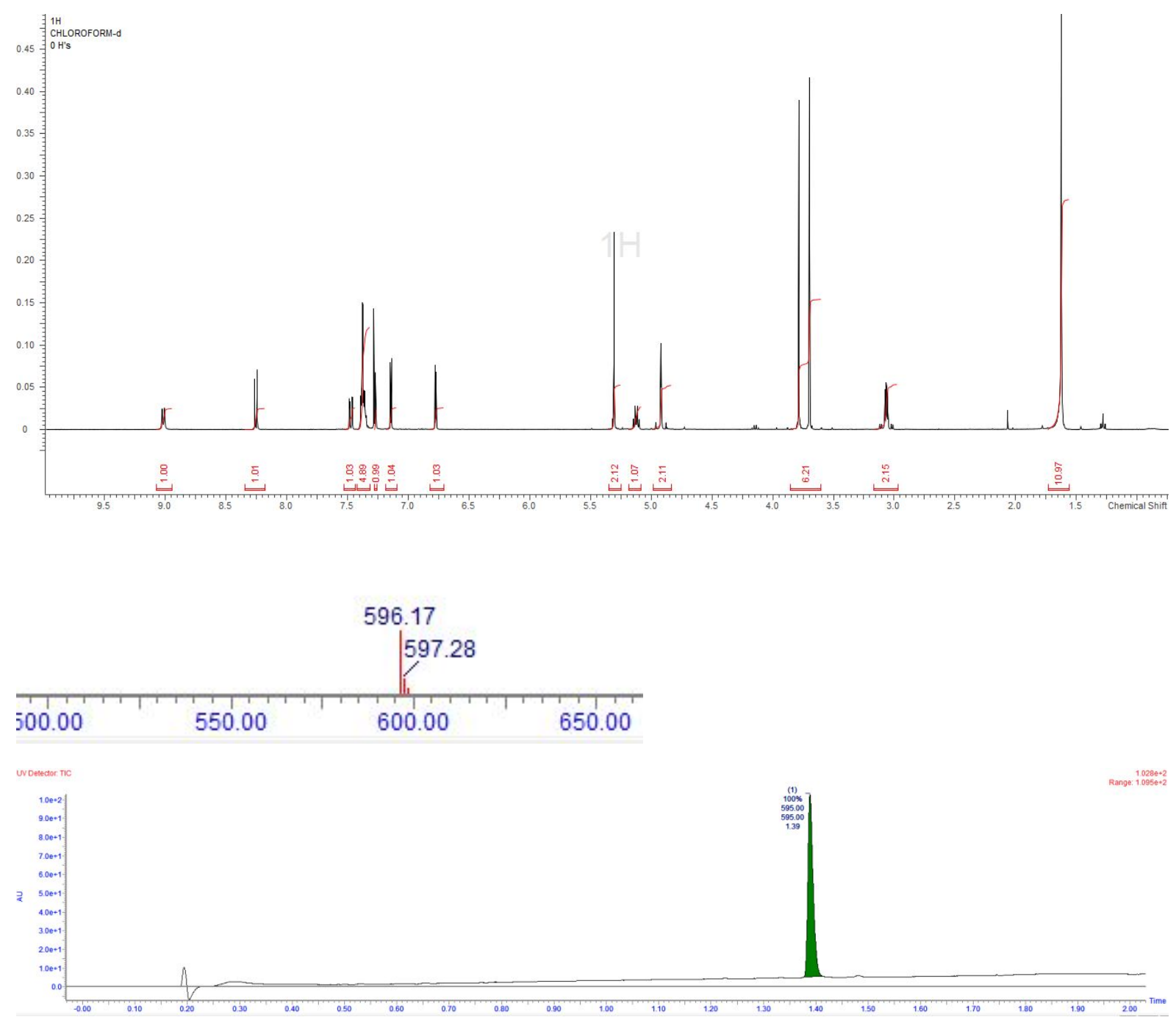

(S)-2-(5-(5-(tert-butoxycarbonyl)furan-2-yl)-2-((1,4-dimethoxy-1,4-dioxobutan-2yl)carbamoyl)phenoxy)acetic acid (6)<smiles>CCCCOC(=O)c1ccc(-c2ccc(C(=O)N[C@@H](CC(C)=O)C(C)C)c(OCC(=O)O)c2)o1</smiles>

5 (650 mg, $1.091 \mathrm{mmol}$ ) was dissolved in methanol (10 mL), degassed with nitrogen and palladiun 10\% on carbon, 50\% wet (65 mg, E101 NE/W) was added. The mixture was degassed with nitrogen and then stirred under hydrogen at room temperature for $2 \mathrm{~h}$. The reaction mixture was filtered through celite under a nitrogen atmosphere to remove the $\mathrm{Pd} / \mathrm{C}$. The filtrate was concentrated under reduced pressure to provide 6 (536 mg. 97\% yield). $\left.{ }^{1} \mathrm{H} \mathrm{NMR} \mathrm{(400} \mathrm{MHz,} \mathrm{CDCl} 3\right): 8.78(\mathrm{br} \mathrm{d}, J=7.5 \mathrm{~Hz}, 1 \mathrm{H}$ ), 8.11 (d, $J=8.5 \mathrm{~Hz}, 1 \mathrm{H}), 7.46(\mathrm{~m}, 1 \mathrm{H}), 7.16$ (d, $J=3.53 \mathrm{~Hz}, \mathrm{H}), 6.84$ (d, $J=3.53 \mathrm{~Hz}, \mathrm{H}), 5.2-5.10$ (m, $1 \mathrm{H}), 4.85-4.95(\mathrm{~m}, 2 \mathrm{H}), 3.80(\mathrm{~s}, 3 \mathrm{H}), 3.70(\mathrm{~s}, 3 \mathrm{H}), 2.97-3.17(\mathrm{~m}, 2 \mathrm{H}), 1.63(\mathrm{~s}, 9 \mathrm{H})$ (plus hydrogenated related impurities) MS: $[\mathrm{M}-\mathrm{H}]^{-} 504$ 

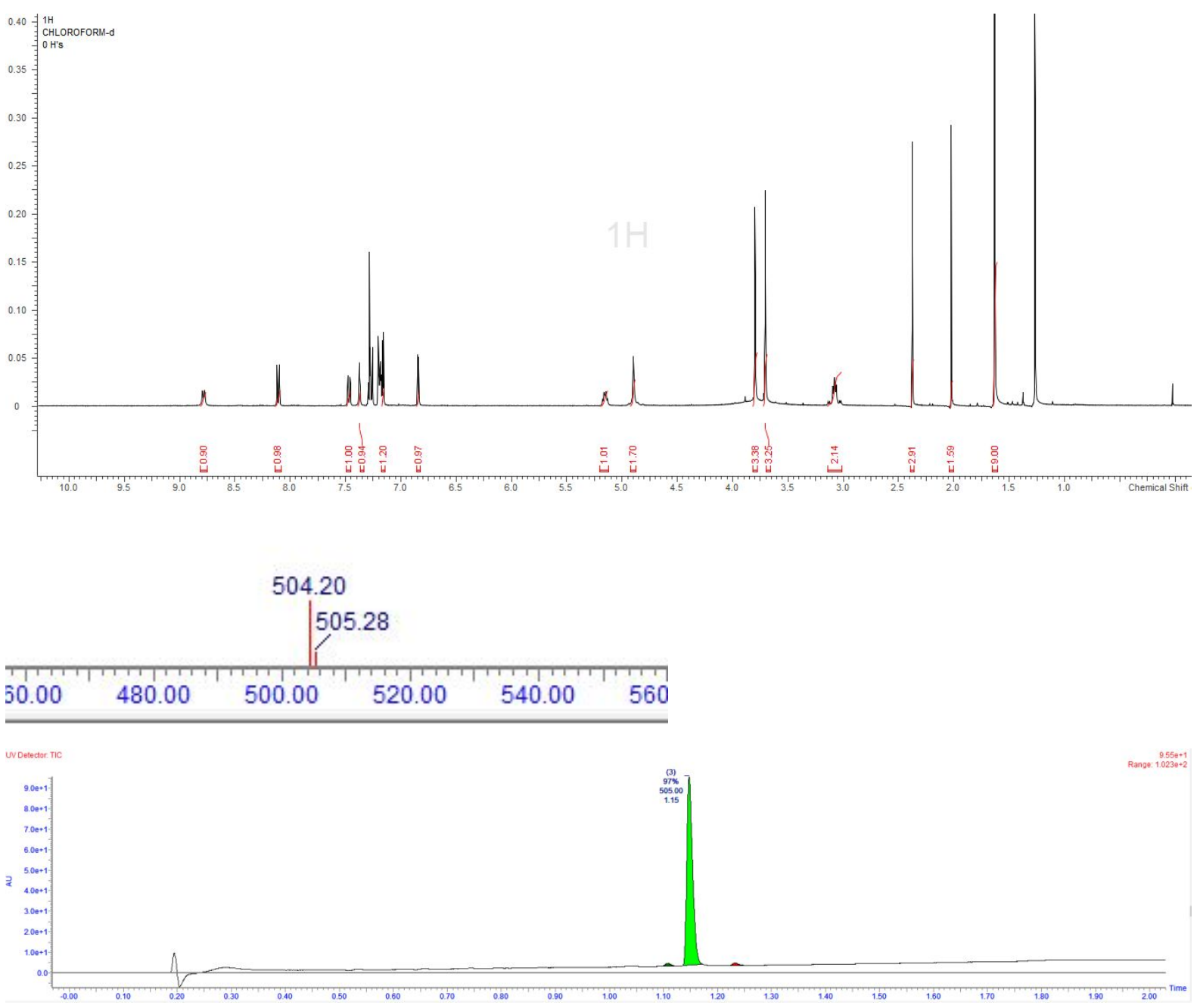

(S)-1-(5-(5-(tert-butoxycarbonyl)furan-2-yl)-2-((1,4-dimethoxy-1,4-dioxobutan-2yl)carbamoyl)phenoxy)-2-oxo-6,9,12,15,18,21,24,27,30,33,36,39-dodecaoxa-3-azadotetracontan42-oic acid (7)<smiles>CCCOC(=O)c1ccc(-c2ccc(C(=O)N[C@@H](CC(=O)OC)C(=O)OC)c(OCC(=O)NCCCOCCC(=O)O)c2)o1</smiles>

Disuccinimidyl carbonate $(230 \mathrm{mg}, 0.898 \mathrm{mmol})$ and pyridine $(0.073 \mathrm{~mL}, 0.898 \mathrm{mmol})$ were added to a solution of $6(454 \mathrm{mg}, 0.898 \mathrm{mmol})$ in acetonitrile $(2.5 \mathrm{~mL})$. The reaction mixture was stirred overnight at room temperature. Additional disuccinimidyl carbonate $(100 \mathrm{mg})$ and pyridine (30ul) were added and stirred for a further $3 \mathrm{~h}$. The mixture was concentrated under reduced pressure and partitioned between dichloromethane and $1 \mathrm{~N}$ hydrochloric acid. The organic phase was washed with saturated aqueous sodium bicarbonate, brine, dried over magnesium sulfate, filtered and 
concentrated under reduced pressure. The crude succinate ester was dissolved in acetonitrile $(2.5 \mathrm{ml})$ and $\mathrm{H} 2 \mathrm{~N}$-dPEG12)-CO2H ( $555 \mathrm{mg}, 0.898 \mathrm{mmol}$ ) was added and the mixure stirred for $2 \mathrm{~h}$. The solvent was removed under reduced pressure and the product purified by reverse phase chromatography [Biotage 120g, 5-60\% acetonitrile/ water ( $1 \%$ formic acid)] and lyophilized to provide 7 (677 mg, 68.2\% yield). ${ }^{1} \mathrm{H}$ NMR ( $\left.400 \mathrm{MHz}, \mathrm{CDCl}_{3}\right): 8.43$ (br d, $\left.J=7.5 \mathrm{~Hz}, 1 \mathrm{H}\right), 8.1$ (br d, $\left.J=8.1 \mathrm{~Hz}, 1 \mathrm{H}\right), 7.50$ (br d, $J=8.1 \mathrm{~Hz}, 1 \mathrm{H}), 7.40-7.47(\mathrm{~m}, 1 \mathrm{H}), 7.37(\mathrm{br} \mathrm{s}, 1 \mathrm{H}), 7.17$ (br d, $J=3.5 \mathrm{~Hz}, 1 \mathrm{H}), 6.86$ (d, $J=3.5$ $\mathrm{Hz}, 1 \mathrm{H}), 5.30$ (DCM), $5.07-5.16(\mathrm{~m}, 1 \mathrm{H}), 4.80(\mathrm{~m}, 2 \mathrm{H}), 3.76-3.84(\mathrm{~m}, 5 \mathrm{H}), 3.55-3.73(\mathrm{~m}, 48$ H), ) $3.0-3.2(m, 2 H), 2.58-2.66(m, 2 H), 1.60(s, 9 H) M S:[M+H]^{+} 1105$

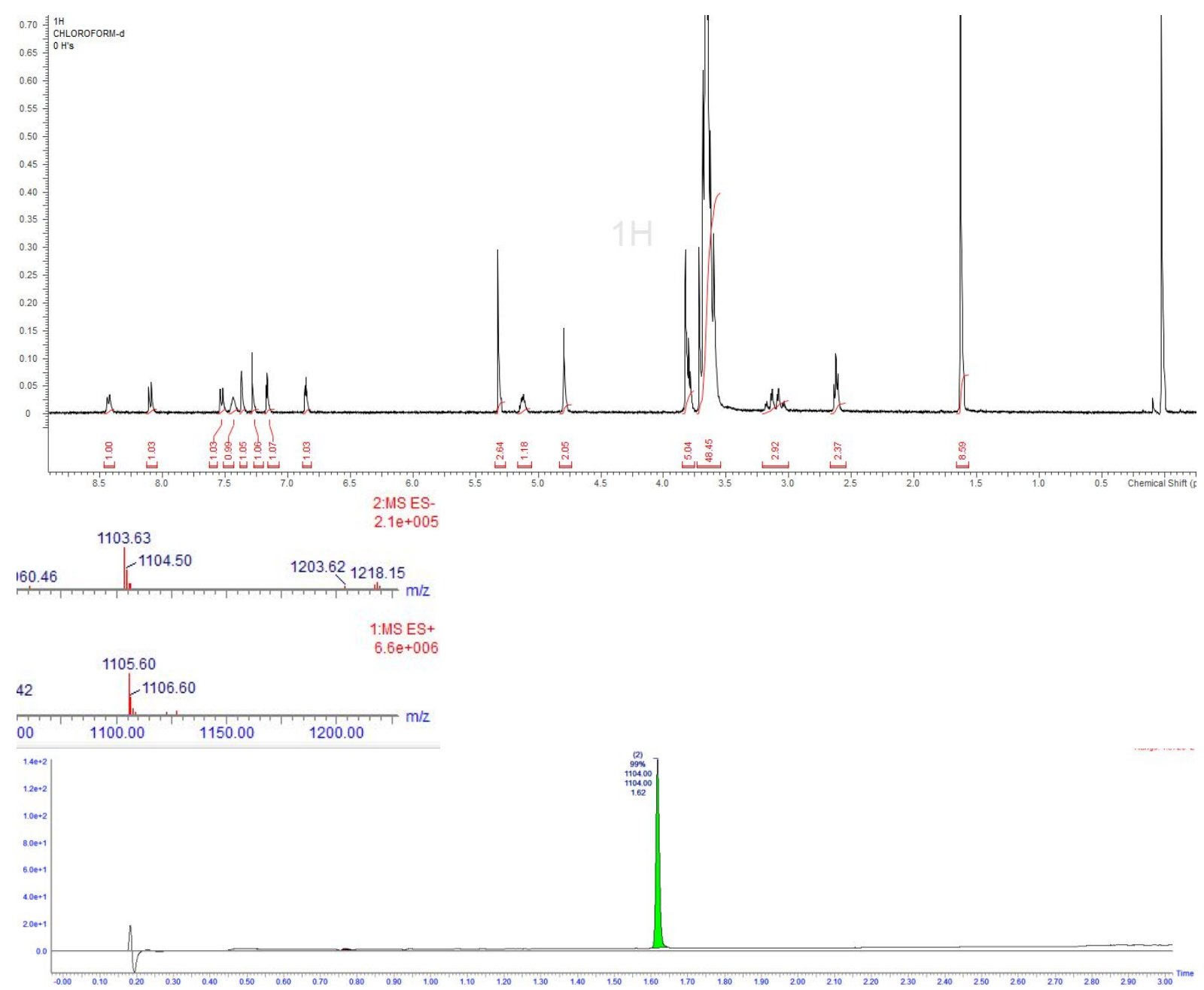

1-(4-(1H-benzo[d]imidazol-2-yl)benzoyl)piperidin-4-yl (3-((2-(2-(2-

aminoethoxy)ethoxy)ethyl)carbamoyl)phenyl)carbamate trifluoroacetate salt (8) was prepared by the published procedure: Benzimidazole derivatives for affinity chromatography and extending the half-life of a therapeutic agent, PCT Int. Appl. (2015), WO 2015049651.

Dimethyl(2-((1-(3-)(((1-(4-(1H-benzo[d]imidazol-2-yl)benzoyl)piperidin-4-

yl)oxy)carbonyl)amino)phenyl)-1,12,52-trioxo-5,8,15,18,21,24,27,30,33,36,39,42,45,48-

tetradecaoxa-2,11,51-triazatripentacontan-53-yl)oxy)-4-(5-(tert-butoxycarbonyl)furan-2-

yl)benzoyl)-L-aspartate (9) 
<smiles>CCCCOC(=O)c1ccc(-c2ccc(C(=O)NC(CC(=O)OC)C(=O)OC)c(OCC(=O)NCCOCCC(=O)NCCOCCOCCNC(=O)c3cccc(NC(=O)OC4CCN(C(=O)c5ccc(-c6nc7ccccc7[nH]6)cc5)CC4)c3)c2)o1</smiles>

The product is the result of three reactions

1) Disuccinimidyl carbonate $(11.6 \mathrm{mg}, 0.045 \mathrm{mmol})$ and pyridine $(7.32 \mu \mathrm{l}, 0.090 \mathrm{mmol})$ were added to a solution of acid $7(50 \mathrm{mg}, 0.045 \mathrm{mmol})$ in acetonitrile $(0.25 \mathrm{~mL})$. The reaction mixture was stirred for $2 \mathrm{~h}$ at room temperature. Additional disuccinimidyl carbonate (11.6 $\mathrm{mg}, 0.045 \mathrm{mmol})$ and pyridine $(7.32 \mu \mathrm{l}, 0.090 \mathrm{mmol})$ were added and stirred for a further $2 \mathrm{~d}$. $8(66.0 \mathrm{mg}, 0.090 \mathrm{mmol})$ was added to the reaction and the mixture stirred for $17 \mathrm{~h}$.

2) N,N-Diisopropylethylamine ( $32 \mu \mathrm{L}, 0.181 \mathrm{mmol}$ ) was added to a stirred solution of 8 ( $33.0 \mathrm{mg}$, $0.045 \mathrm{mmol}$ ), acid 7 (50 mg, $0.045 \mathrm{mmol})$ and HATU (17.2 $\mathrm{mg}, 0.045 \mathrm{mmol})$ in DMF (0.25 ml) and the mixture stirred for $2 \mathrm{~h}$ at room temperature.

3) N,N-Diisopropylethylamine ( $63 \mu \mathrm{L}, 0.362 \mathrm{mmol}$ ) was added to a stirred solution of $8(66.0 \mathrm{mg}$, $0.090 \mathrm{mmol}$ ), acid 7 (100 $\mathrm{mg}, 0.090 \mathrm{mmol}$ ) and HATU $(34.4 \mathrm{mg}, 0.09 \mathrm{mmol})$ in DMF $(0.5 \mathrm{ml})$ and the mixture stirred for $2 \mathrm{~h}$ at room temperature.

The combined reaction mixtures were purified by reverse phase chromatography [Biotage 40g, 5-50\% acetonitrile/ water ( $1 \%$ formic acid)] and lyophilized to provide the title compound (150mg, 50\% yield)- still contaminated with $6 \%$ starting material. ${ }^{1} \mathrm{H}$ NMR $\left.(400 \mathrm{MHz}, \mathrm{DMSO}-\mathrm{D} 6)\right)$ MS: $[\mathrm{M}+\mathrm{H}]^{+}$ 1701.
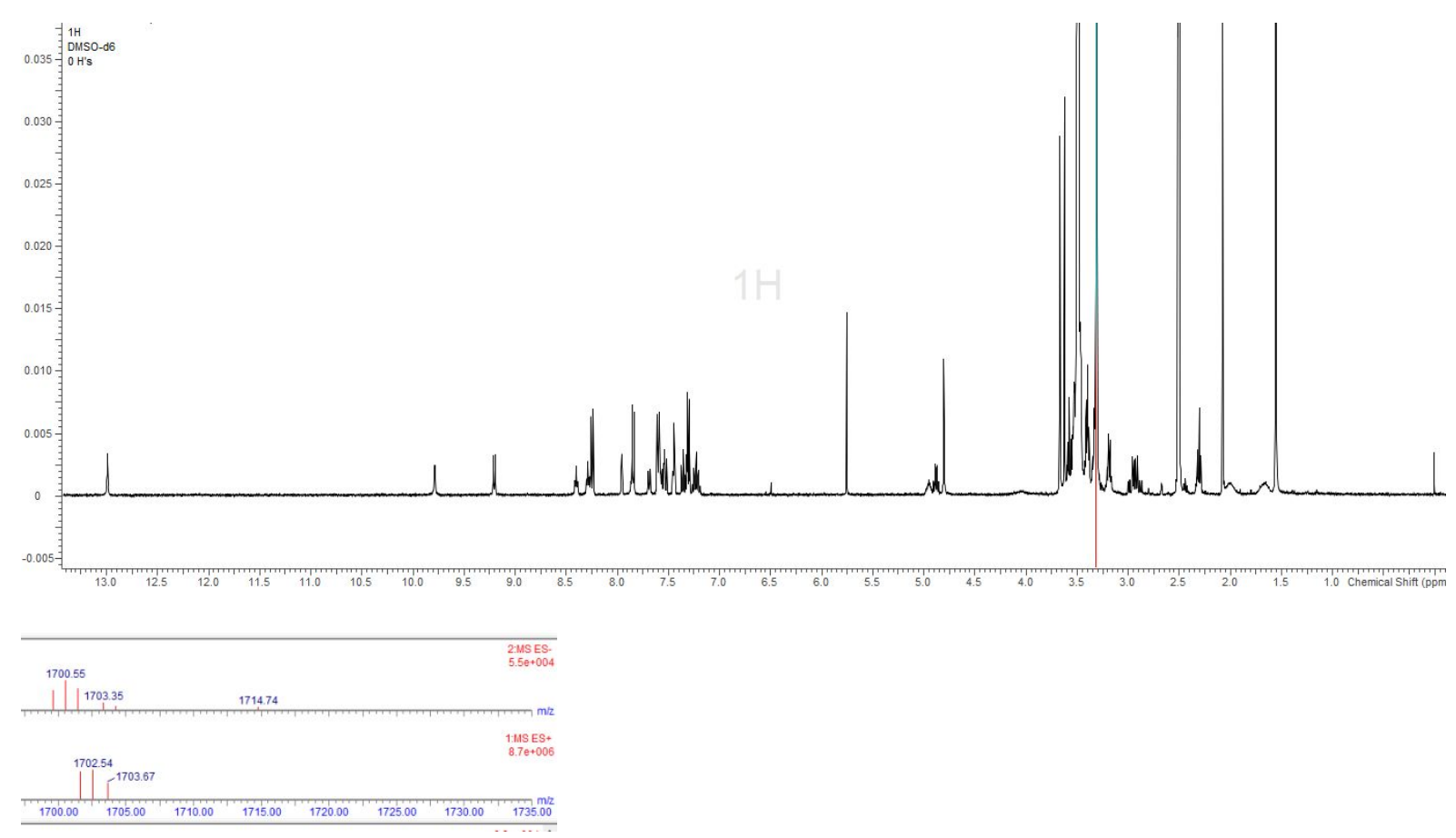


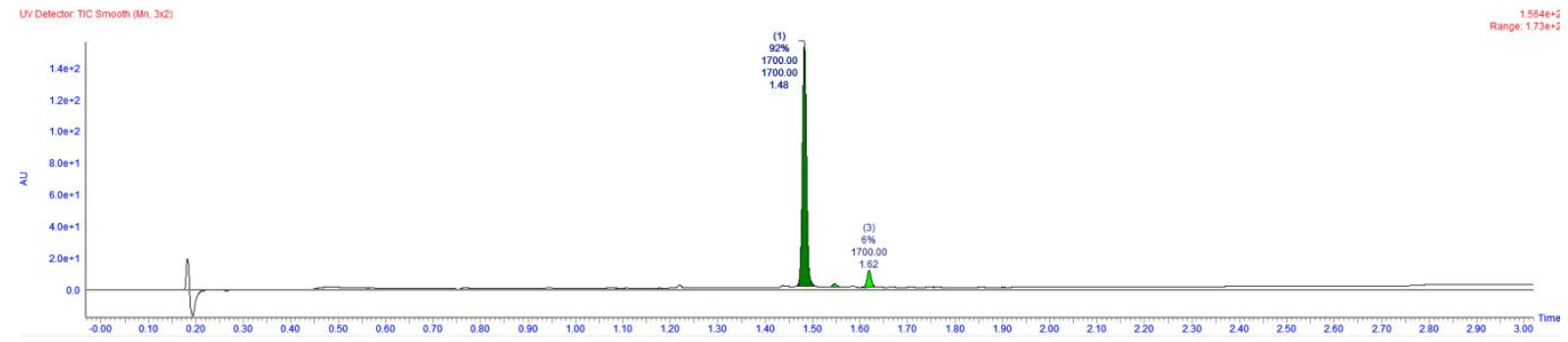

Contains $\sim 6 \%$ of starting acid

(R)-N-(aminomethyl)-2-((R)-1-(N-hydroxyformamido)propyl)heptanamide (11) was prepared by the published procedure: Preparation of furanyl N-hydroxyformamide compounds and compositions comprising them for use as BMP1, TLL1 and/or TLL2 inhibitors, PCT Int. Appl. (2017), WO

2017006296.

Dimethyl(2-((1-(3-)(((1-(4-(1H-benzo[d]imidazol-2-yl)benzoyl)piperidin-4-

yl)oxy)carbonyl)amino)phenyl)-1,12,52-trioxo-5,8,15,18,21,24,27,30,33,36,39,42,45,48-

tetradecaoxa-2,11,51-triazatripentacontan-53-yl)oxy)-4-(5-((((R)-2-((R)-1-(N-

hydroxyformamido)propyl)heptanamido)methyl)carbamoyl)furan-2-yl)benzoyl)-L-aspartate (12)

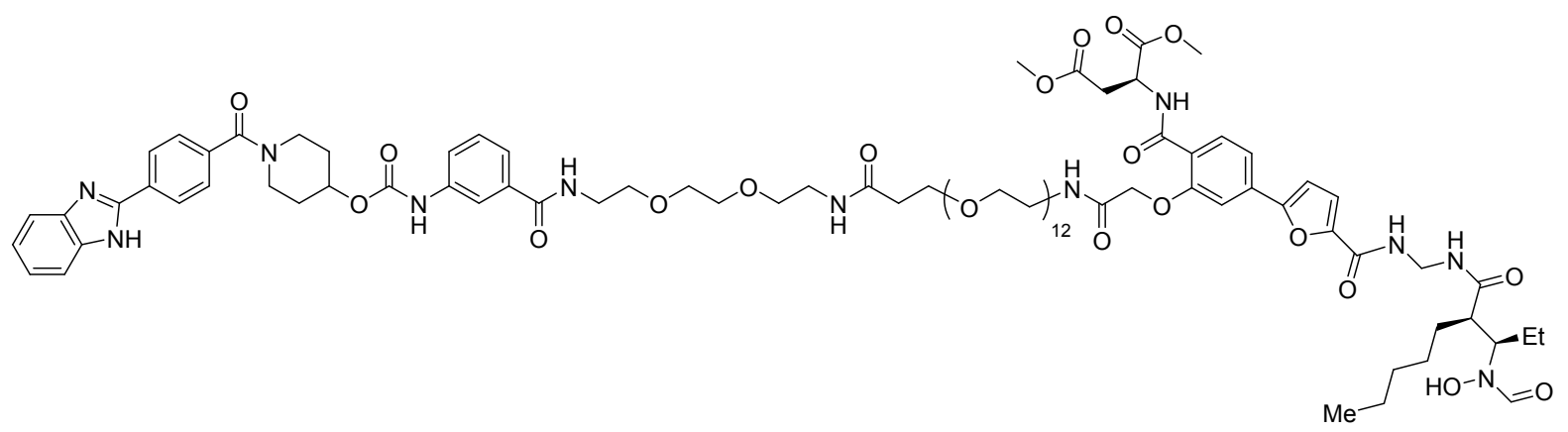

Trifluoroacetic acid $(1 \mathrm{~mL}, 12.98 \mathrm{mmol})$ and a drop of water was added to $9(150 \mathrm{mg}, 0.088 \mathrm{mmol})$ in dichloromethane $(1 \mathrm{~mL})$. The reaction mixture was stirred at room temperature for $2 \mathrm{~h}$, concentrated under reduced pressure and then azeotroped with toluene to afford the free acid (10). [MS: $[\mathrm{M}+\mathrm{H}]^{+}$ 1645]. 10 (145 mg, $0.088 \mathrm{mmol})$ and HATU $(50.5 \mathrm{mg}, 0.133 \mathrm{mmol})$ were stirred in DMF $(750 \mu \mathrm{L})$ and $\mathrm{N}, \mathrm{N}$-diisopropylethylamine $(46.2 \mathrm{uL}, 0.264 \mathrm{mmol}$ ) was added. The mixture was stirred for $1.5 \mathrm{~h}$ at room temperature and then $11(41.1 \mathrm{mg}, 0.159 \mathrm{mmol})$ was added and the solution stirred at room temperature for a further $1.5 \mathrm{~h}$. The reaction was partitioned between dichloromethane and saturated aqueous lithium chloride solution. The organic phase was separated and washed with aqueous saturated aqueous sodium bicarbonate, $1 \mathrm{~N}$ hydrochloric acid, brine, dried over magnesium sulfate, filtered and concentrated under reduced pressure. The residue was purified by reverse phase chromatography [Biotage 30g, 5-60\% acetonitrile/ water (1\% formic acid)] to provide the title 12 (99mg, 60\%) and less pure material. MS: $[\mathrm{M}+2 \mathrm{H}]^{+2} 944[\mathrm{M}+3 \mathrm{H}]^{+3} 629$ 


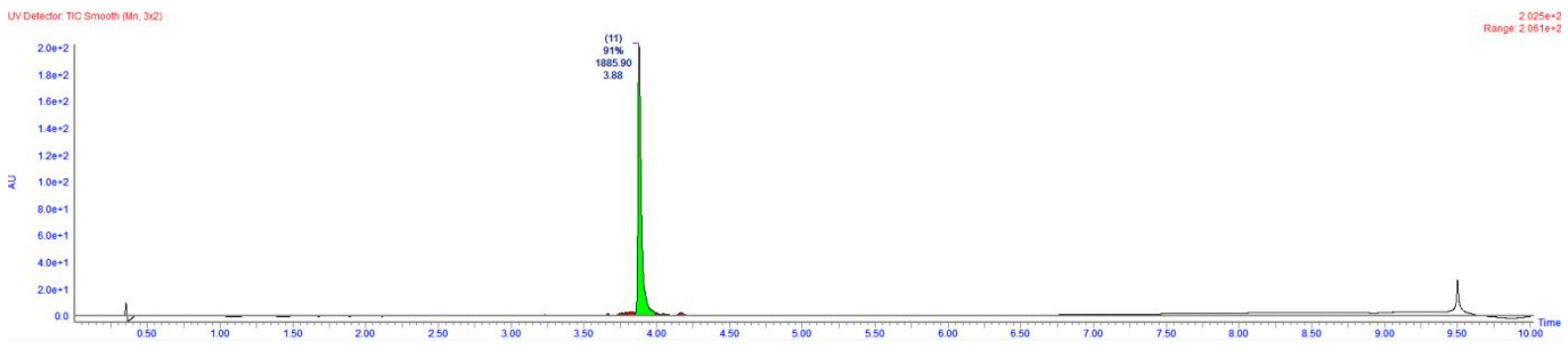

\section{Conjugate c}<smiles></smiles>

12 (99mg, $0.052 \mathrm{mmol}$ ) was dissolved in methanol (500 $\mathrm{LL}$ ) and water (250ul), then lithium hydroxide monohydrate $(22.01 \mathrm{mg}, 0.525 \mathrm{mmol})$ was added and the mixture stirred at room temperature for $2 \mathrm{~h}$. The mixture was purified by reverse phase chromatography [Biotage $30 \mathrm{~g}, 5-60 \%$ acetonitrile/ water (1\% formic acid)] and then repurified by reverse phase chromatography [Biotage 30g, 5-30\% acetonitrile/ $10 \mathrm{mM}$ ammonium bicarbonate $(\mathrm{pH} 10)$ ] and lyophilized to provide conjugate c (52 mg, $52.4 \%$ yield). ${ }^{1} \mathrm{H}$ NMR (400 MHz, DMSO-D6) ) HRMS (ESI): m/z calcd. for C90H127N11031 [M + H] ${ }^{+}$ 1858.8778 , found 1858.8704 .
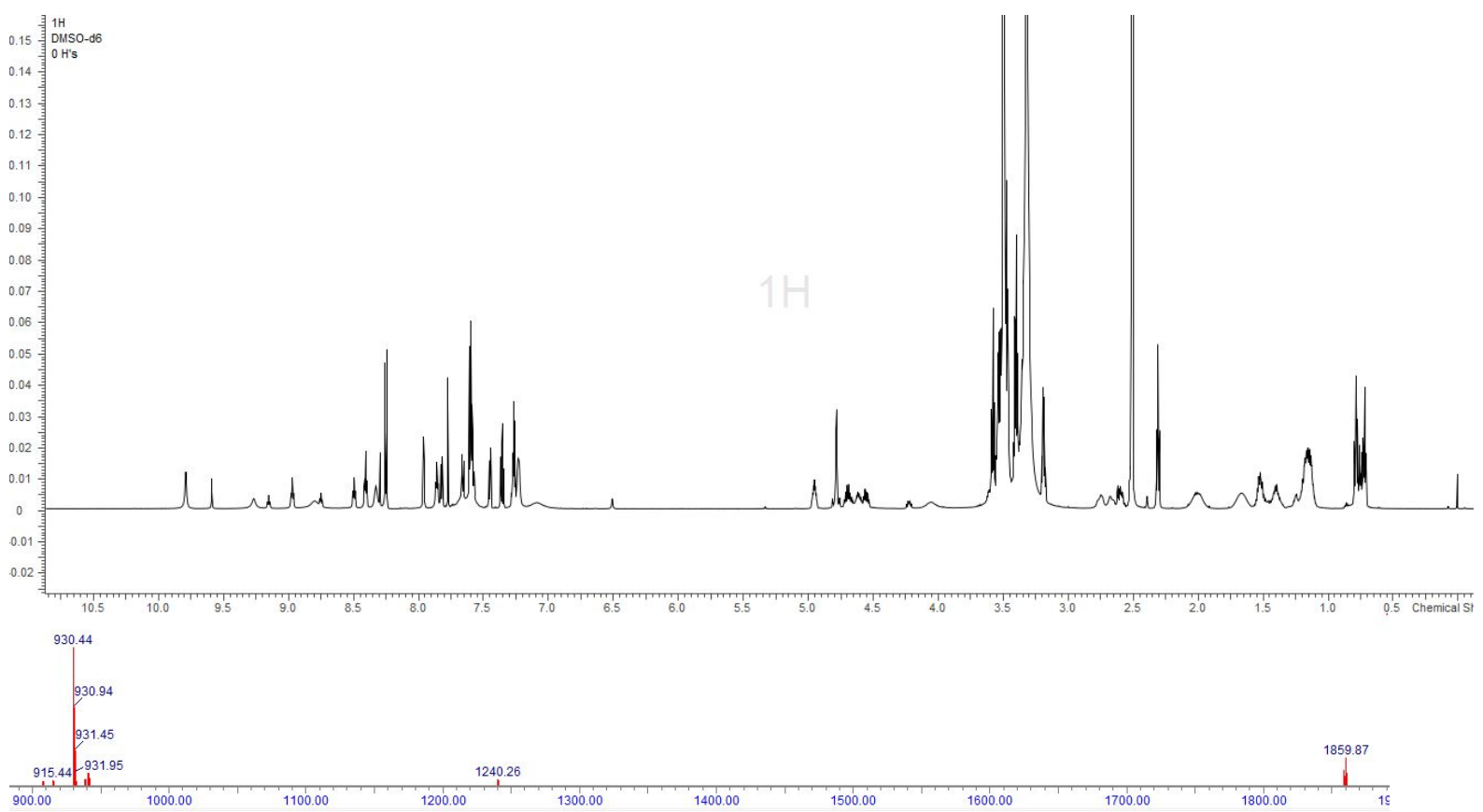


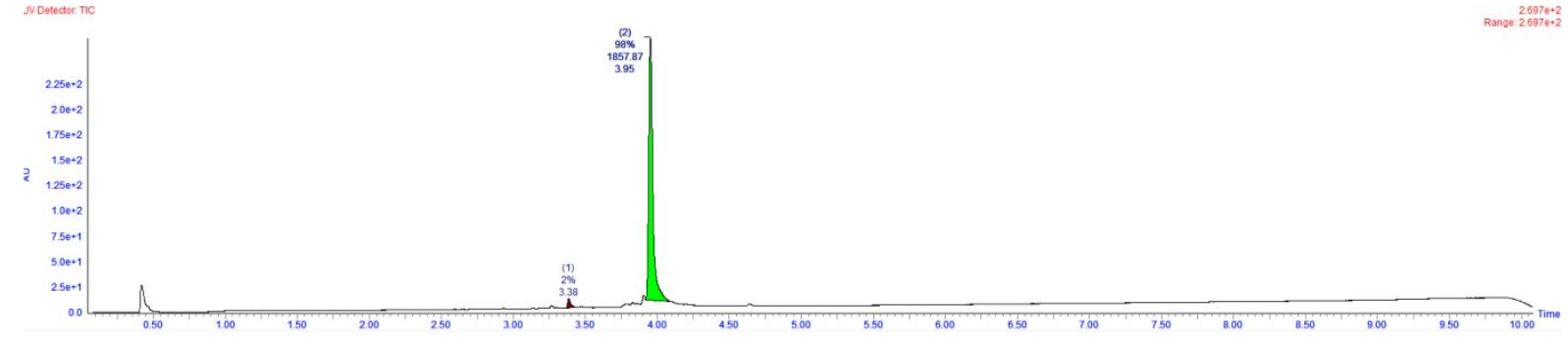

\section{Conjugate a}

$91 \mathrm{mg}$ of conjugate a were obtained using a strategy analogous to conjugate $\mathrm{c}$. HRMS (ESI): $\mathrm{m} / \mathrm{z}$ calcd. for $\mathrm{C}_{86} \mathrm{H}_{124} \mathrm{~N}_{10} \mathrm{O}_{26}[\mathrm{M}+2 \mathrm{H}] 2+/ 2$ 857.4423, found 857.4434 .

\section{Conjugate $b$}

$40 \mathrm{mg}$ of conjugate $\mathrm{b}$ were obtained using a strategy analogous to conjugate $\mathrm{c}$.

HRMS (ESI): $\mathrm{m} / \mathrm{z}$ calcd. for $\mathrm{C}_{86} \mathrm{H}_{124} \mathrm{~N}_{10} \mathrm{O}_{26}[\mathrm{M}+2 \mathrm{H}] 2+/ 2$ 921.9630, found 921.9622 .

\section{Conjugate $\mathbf{d}$}

$23 \mathrm{mg}$ of conjugate $\mathrm{d}$ were obtained using a strategy analogous to conjugate $\mathrm{c}$. HRMS (ESI): $\mathrm{m} / \mathrm{z}$ calcd. for $\mathrm{C}_{63} \mathrm{H}_{74} \mathrm{~N}_{10} \mathrm{O}_{18}[\mathrm{M}+\mathrm{H}]+1259.5261$, found 1259.5247 .

\section{Conjugate e}

$48 \mathrm{mg}$ of conjugate e were obtained using a strategy analogous to conjugate c. HRMS (ESI): $\mathrm{m} / \mathrm{z}$ calcd. for $\mathrm{C}_{77} \mathrm{H}_{132} \mathrm{~N}_{6} \mathrm{O}_{25}[\mathrm{M}+\mathrm{H}]+1541.9320$, found 1541.9325 . 